Artikel Penelitian

\title{
Hubungan Ansietas dan Depresi dengan Derajat Dispepsia Fungsional di RSUP Dr M Djamil Padang Periode Agustus 2013 hingga Januari 2014
}

\author{
Dita Nelvita Sari ${ }^{1}$, Arina Widya Murni ${ }^{2}$, Edison $^{3}$
}

\begin{abstract}
Abstrak
Dispepsia fungsional merupakan salah satu jenis dispepsia yang paling sering ditemukan pada masyarakat. Banyak faktor yang dapat memicu derajat keluhan pada penderita dispepsia fungsional, salah satunya gangguan psikologis terutama ansietas dan depresi. Tujuan penelitian ini adalah menentukan hubungan ansietas dan depresi dengan derajat dispepsia fungsional. Penelitian ini dilakukan terhadap pasien RSUP Dr M Djamil Padang yang berobat dari Agustus 2013 hingga Januari 2014. Penelitian ini merupakan penelitian analitik observasional dengan pendekatan cross sectional dengan jumlah sampel 32 orang. Data dari responden dikumpulkan dengan cara wawancara, ansietas dan depresi dinilai dengan Hospital Anxiety and Depression Scale (HADS) dan derajat dispepsia fungsional dinilai dengan Skor Dispepsia. Analisis statistik yang digunakan adalah uji chi-square. Hasil penelitian menemukan bahwa $37,5 \%$ mengalami derajat dispepsia berat, 50\% mengalami derajat dispepsia sedang, dan 12,5\% mengalami derajat dispepsia ringan. Ansietas dialami oleh $37,5 \%$ penderita dispepsia fungsional dan depresi dialami oleh $12,5 \%$ penderita dispepsia fungsional. Berdasarkan hasil uji statistik chi square didapatkan bahwa ada hubungan yang bermakna antara ansietas dengan derajat dispepsia fungsional $(p<0,05)$ dan tidak ada hubungan yang bermakna antara depresi dengan dispepsia fungsional $(p>0,05)$. Temuan ini menunjukkan bahwa ada hubungan yang bermakna antara ansietas dengan derajat dispepsia fungsional tetapi tidak dengan depresi.
\end{abstract}

Kata kunci: ansietas, depresi, dispepsia fungsional

\begin{abstract}
Functional dyspepsia is common type of dyspepsia in the community. Many factors may trigger functional dyspepsia, one of them is psychological disorders, especially anxiety and depression. The objective of this study was to investigate the relationship between anxiety and depression on the degree of functional dyspepsia. The study was conducted at RSUP Dr M Djamil Padang from August 2013 to January 2014 using an observational analytic study with cross sectional approach. Thirty-two respondents were interviewed to measure their anxiety and depression using the Hospital Anxiety and Depression Scale (HADS). Functional dyspepsia degree was measured using dyspepsia score. The statistical analysis used was chi square test. Results found that $37.5 \%$ patients having a severe symptoms, $50 \%$ having a moderate symptoms, and $12.5 \%$ having a mild symptoms. Anxiety and depression were $37.5 \%$ and $12.5 \%$ respectively among patients. Chi square statistical test showed there was a significant relationship between anxiety and the degree of functional dyspepsia $(p<0.05)$ and no significant correlation between depression and the degree of functional dyspepsia ( $p>0.05)$. These finding suggest that there was a significant relationship between anxiety but not a depression and the degree of functional dyspepsia.
\end{abstract}

Keywords: anxiety, depression, functional dyspepsia

Affiliasi penulis: 1. Prodi Profesi Dokter FK Unand (Faklutas Kedokteran Universitas Andalas Padang). 2. Bagian IImu Penyakit Dalam FK Unand. 3. Bagian IImu Kesehatan Masyarakat FK Unand
Korespondensi: Dita Nelvita Sari, Email: ditanelvita@yahoo.co.id, Telp: 08136457579291 


\section{PENDAHULUAN}

Sindroma dispepsia merupakan masalah kesehatan yang sering ditemukan pada masyarakat, yang ditandai dengan gelaja yang kompleks berupa nyeri epigastrik, kembung, mual, muntah, sendawa, rasa penuh, mudah kenyang, dan rasa terbakar di epigastrik. Sindroma dispepsia ini menyebabkan angka kesakitan yang tinggi pada masyarakat, dimana di Amerika Serikat dan negara Eropa lainnya didapatkan prevalensi sindroma dispepsia berkisar antara $23 \%$ hingga $41 \%$. Data yang diperoleh dari Depkes RI tahun 2010 juga menunjukkan tingginya prevalensi dispepsia di Indonesia, dimana dispepsia menempati urutan ke-5 pada daftar pola 10 penyakit terbanyak pada pasien rawat inap di RS di Indonesia dengan jumlah 9.594 pasien laki-laki dan 15.122 pasien perempuan, dan menimbulkan kematian pada 166 orang, serta menempati urutan ke-6 pada daftar pola 10 penyakit terbanyak pada pasien rawat jalan dengan jumlah 34.981 pasien laki-laki dan 53.618 pasien perempuan dengan jumlah kasus dispepsia baru sebesar 88.599 kasus. $^{1-3}$

Dispepsia fungsional merupakan salah satu jenis dispepsia dimana setelah dilakukan test diagnostik tidak ditemukan adanya penyakit organik yang mendasarinya. Proporsi dispepsia fungsional ini juga ditemukan lebih tinggi dibandingkan dispepsia organik dimana berdasarkan penelitian yang dilakukan pada 1001 subjek di Swedia, didapatkan proporsi dispepsia fungsional pada penderita dispepsia adalah sebesar $77,7 \%$, sedangkan prevalensi penderita dispepsia adalah sebesar 20,2\%. Penderita dispepsia fungsional ini akan mengalami penurunan kualitas hidupnya baik berupa ketegangan, pembatasan aktifitas sehari-hari, terganggu dalam makan dan minum, berfikiran akan terus menerus mengalami gejala dispepsia tersebut, dan pembatasan aktivitas kerja, sehingga pada akhirnya akan menurunkan kualitas sumber daya manusia pada negara-negara yang memiliki prevalensi dispepsia yang tinggi. ${ }^{2,4,5}$

Pasien dispepsia fungsional mengalami berbagai derajat dispepsia fungsional (ringan, sedang, dan berat) yang diperkirakan berhubungan dengan gangguan psikologis, dan diduga sebagai salah satu faktor penyebab dispepsia fungsional dimana interaksi faktor psikologis dengan gangguan saluran cerna berupa dispepsia fungsional ini diyakini melalui mekanisme brain-gut-axis. Mereka berkomunikasi secara dua arah melalui sistem saraf otonom (SSO) dan hypothalamic-pituitary-adrenal (HPA) axis. Komunikasi dua arah ini menggabungkan beragam pengaruh faktor kognitif/psikologis, persepsi viseral, dan abnormalitas motorik sehingga memungkinkan gangguan psikologis menyebabkan timbulnya dispepsia fungsional dan begitu pula sebaliknya. ${ }^{6}$

Gangguan psikologis yang sering dikaitkan menimbulkan gangguan gastrointestinal adalah ansietas atau depresi, dimana berdasarkan penelitian menggunakan kuesioner Hospital Anxiety and Depression Index (HADS) yang dilakukan di Norwegia didapatkan bahwa ansietas dan depresi berhubungan dengan gangguan gastrointestinal dimana hubungan ansietas dan depresi ini dengan gangguan gastrointestinal ini bukan hanya merupakan konsekuensi akibat mengalami penyakit gastrointestinal tapi merupakan bagian dari penyakit itu sendiri, dimana ansietas berhubungan kuat dengan gejala nausea, dan juga selain itu berhubungan dengan nyeri dada, diare, dan konstipasi meskipun tidak sekuat nausea. Sedangkan depresi sendiri juga berhubungan dengan timbulnya gejala gastrointestinal meskipun tidak sekuat ansietas. Selain itu penelitian lain mengenai ansietas juga didapatkan bahwa ansietas berhubungan dengan keluhan post prandial distress syndrome pada dispepsia fungsional, yang kemungkinan didasari oleh mekanisme gangguan akomodasi fundus dan hipersensitivitas viseral. Demikian pula dengan depresi, berdasarkan penelitian yang dilakukan oleh Tarigan, didapatkan angka 63,6\% depresi pada pasien dispepsia fungsional yang ditelitinya, sedangkan pada pasien dispepsia organik hanya didapatkan sebesar $36,4 \%$ depresi. Maka oleh karena itu penting juga untuk diketahui lebih lanjut mengenai efek ansietas dan depresi ini terhadap derajat dispepsia fungsional, apakah berkorelasi, dan manakah diantara ansietas dan depresi yang menimbulkan derajat terberat, guna membantu penanganan dispepsia fungsional dikemudian hari. ${ }^{4,7,8}$ Dilatarbelakangi oleh uraian diatas, maka penelitian ini bertujuan adalah untuk melihat hubungan 
ansietas dan depresi terhadap derajat dispepsia fungsional, untuk menilai ada tidaknya ansietas dan depresi pada penderita dispepsia fungsional sebagai salah satu aspek yang dapat membantu proses terapi penderita dispepsia fungsional.

\section{METODE}

Rancangan penelitian yang digunakan dalam penelitian ini adalah analitik observasional. Dalam penelitian ini yaitu untuk mencari hubungan antara ansietas dan depresi dengan derajat keluhan dispepsia fungsional dilakukan dengan pendekatan potong lintang (cross sectional).

Penelitian dilakukan langsung ke rumah pasien dispepsia fungsional berdasarkan data IDT (Instalasi Diagnosis Terpadu) RSUP Dr M Djamil Padang dan dilakukan pada bulan Desember 2013 sampai Maret 2014.

Populasi dalam penelitian ini adalah pasien penderita dispepsia fungsional berdasarkan data IDT (Instalasi Diagnosis Terpadu) RSUP Dr M Djamil Padang yang berobat pada bulan Agustus 2013 hingga Januari tahun 2014. Pengambilan data secara total sampling, yakni seluruh pasien dispepsia fungsional berdasarkan data IDT (Instalasi Diagnosis Terpadu) RSUP Dr M Djamil Padang yang berobat pada bulan Oktober hingga Desember tahun 2013.

\section{HASIL}

Pada penelitian ini didapatkan populasi sebesar 61 orang penderita dispepsia fungsional dengan 32 sampel yang memenuhi kriteria penelitian.

Tabel 1. Distribusi frekuensi responden berdasarkan derajat dispepsia fungsional

\begin{tabular}{ccc}
\hline Derajat Dispepsia & Frekuensi & $\%$ \\
\hline Berat & 12 & 37,5 \\
Sedang & 16 & 50 \\
Ringan & 4 & 12,5 \\
\hline Total & 32 & 100 \\
\hline
\end{tabular}

Berdasarkan Tabel 1, dapat dilihat bahwa pada responden terdapat 12 orang $(37,5 \%)$ mengalami derajat dispepsia berat, 16 orang $(50 \%)$ mengalami derajat dispepsia sedang, dan 4 orang (12,5\%) mengalami derajat dispepsia ringan.

Tabel 2. Distribusi frekuensi responden berdasarkan gangguan psikologis penderita dispepsia fungsional

\begin{tabular}{ccc}
\hline $\begin{array}{c}\text { Gangguan } \\
\text { Psikologis }\end{array}$ & Frekuensi & $\%$ \\
\hline Ansietas & 12 & 37,5 \\
Ansietas - depresi & 1 & 3,1 \\
Depresi & 4 & 12,5 \\
Normal & 15 & 46,9 \\
\hline Total & 32 & 100 \\
\hline
\end{tabular}

Berdasarkan Tabel 2, dapat dilihat bahwa pada responden terdapat 12 orang $(37,5 \%)$ yang mengalami ansietas, 5 orang $(12,5 \%)$ yang mengalami depresi, satu orang $(3,1 \%)$ yang mengalami campuran ansietas dan depresi, dan 15 orang $(46,9 \%)$ normal.

Tabel 3. Hubungan ansietas dengan derajat dispepsia responden penderita dispepsia fungsional

\begin{tabular}{|c|c|c|c|c|c|c|c|}
\hline \multirow[t]{3}{*}{ Ansietas } & \multicolumn{6}{|c|}{ Derajat Dispepsia } & \multirow{3}{*}{$\mathbf{p}$} \\
\hline & \multicolumn{2}{|c|}{ Berat } & \multicolumn{2}{|c|}{ Sedang } & \multicolumn{2}{|c|}{ Ringan } & \\
\hline & $f$ & $\%$ & $f$ & $\%$ & $f$ & $\%$ & \\
\hline \multirow[t]{2}{*}{$\mathrm{Ya}$} & 8 & 66,7 & 3 & 25 & 1 & 8,3 & 0,015 \\
\hline & & $\%$ & & $\%$ & & $\%$ & \\
\hline \multirow[t]{2}{*}{ Tidak } & 3 & 15,8 & 13 & 68,4 & 3 & 15,8 & \\
\hline & & $\%$ & & $\%$ & & $\%$ & \\
\hline \multirow[t]{2}{*}{ Total } & 11 & 35,5 & 16 & 51,6 & 4 & 12,9 & \\
\hline & & $\%$ & & $\%$ & & $\%$ & \\
\hline
\end{tabular}

Berdasarkan Tabel 3, responden yang dinilai berjumlah 31 orang dari total keseluruhan 32 orang responden. Hal ini dikarenakan terdapat satu orang responden yang mengalami campuran ansietas dan depresi. Berdasarkan tabel tersebut dapat dilihat bahwa ada sebanyak $8(66,7 \%)$ dari 12 responden dengan ansietas yang mengalami derajat dispepsia berat sedangkan di antara responden yang tidak ansietas ada $3(15,8 \%)$ dari 19 responden yang mengalami derajat dispepsia berat. Hasil uji statistik dengan menggunakan chi square, diperoleh nilai $p=$ $0,015(p<0,05)$.Berdasarkan hasil tersebut maka dapat 
disimpulkan bahwa ada hubungan yang bermakna antara ansietas dengan derajat dispepsia fungsional.

Tabel 4. Hubungan depresi dengan derajat dispepsia responden penderita dispepsia fungsional

\begin{tabular}{|c|c|c|c|c|c|}
\hline \multirow[t]{4}{*}{ Depresi } & \multicolumn{4}{|c|}{ Derajat Dispepsia } & \multirow{4}{*}{$\mathbf{p}$} \\
\hline & \multirow{2}{*}{\multicolumn{2}{|c|}{ Berat }} & \multirow{2}{*}{\multicolumn{2}{|c|}{$\begin{array}{c}\text { Sedang- } \\
\text { Ringan }\end{array}$}} & \\
\hline & & & & & \\
\hline & f & $\%$ & f & $\%$ & \\
\hline $\mathrm{Ya}$ & 2 & $50 \%$ & 2 & $50 \%$ & 0,516 \\
\hline Tidak & 9 & $33,3 \%$ & 18 & $66,7 \%$ & \\
\hline Total & 11 & $35,5 \%$ & 20 & $64,5 \%$ & \\
\hline
\end{tabular}

Berdasarkan Tabel 4, responden yang dinilai berjumlah 31 orang dari total keseluruhan 32 orang responden. Hal ini dikarenakan terdapat satu orang responden yang mengalami campuran ansietas dan depresi. Berdasarkan tabel tersebut dapat dilihat bahwa ada 2 (50\%) dari 4 responden dengan depresi yang mengalami derajat dispepsia berat sedangkan di antara responden yang tidak depresi ada 9 (33,3\%) dari 27 responden yang mengalami derajat dispepsia berat. Hasil uji statistik dengan menggunakan chi square, diperoleh nilai $p=0,516 \quad(p>0,05)$. Berdasarkan hasil tersebut dapat disimpulkan bahwa tidak ada hubungan yang bermakna antara depresi dengan derajat dispepsia fungsional.

\section{PEMBAHASAN}

Berdasarkan hasil penelitian yang dilakukan pada 32 orang penderita dispepsia fungsional, didapatkan 12 orang $(37,5 \%)$ mengalami ansietas, sedangkan depresi sendiri hanya terdapat pada 4 orang (12,5\%) penderita dispepsia fungsional. Besarnya jumlah penderita dispepsia fungsional yang mengalami ansietas dibandingkan dengan depresi ini sejalan dengan penelitian yang sebelumnya. ${ }^{9}$

Persentase dari ansietas dan depresi pada penderita dispepsia fungsional yang dilakukan beragam, tetapi berdasarkan penelitian yang dilakukan oleh beberapa ahli, didapatkan bahwa ansietas lebih sering ditemukan pada penderita dispepsia fungsional di bandingkan dengan depresi, meskipun keduanya diduga dapat memperparah gejala dispepsia fungsional melalui mekanisme brain-gut-axis. Perbedaan persentase dari ansietas dan depresi yang dilakukan kemungkinan dapat disebabkan oleh perbedaaan kuesioner atau mekanisme yang digunakan dalam mendeteksi ansietas dan depresi itu sendiri. ${ }^{10}$

Tingginya ansietas pada penderita dispepsia fungsional dapat disebabkan oleh karena pasien yang selalu cemas dengan gejala dispepsia yang dialaminya akan lebih sering mencari pengobatan dibandingkan dengan yang mengacuhkan gejala dispepsianya. Selain itu berdasarkan penelitian yang di lakukan oleh Haug et al pada penderita gangguan gastrointestinal menunjukkan bahwa ansietas berkaitan kuat dengan timbulnya gejala mual dan sakit di ulu hati, sedangkan depresi tidak berkaitan dengan gejala-gejala pada gangguan gastrointestinal tersebut. Penelitian lain menunjukkan mudah kenyang dan rasa penuh setelah makan (post prandial distress syndrome) berkaitan dengan ansietas, tetapi tidak dengan depresi. Keterkaitan yang lebih kuat antara ansietas dengan timbulnya gejala pada dipepsia fungsional dibandingkan dengan depresi ini kemungkinan yang menyebabkan ansietas lebih sering ditemukan pada penderita dispepsia fungsional dibandingkan dengan depresi. ${ }^{4,7,10}$

Hasil penelitian mengenai hubungan ansietas dengan derajat dispepsia didapatkan bahwa proporsi responden yang mengalami derajat dispepsia berat cenderung lebih besar pada responden yang ansietas dibandingkan dengan yang tidak ansietas. Ada sebanyak $66,7 \%$ responden yang mengalami derajat dispepsia berat yang ansietas dan hanya sebanyak $15,8 \%$ responden yang mengalami derajat dispepsia berat yang tidak ansietas. Hasil dari uji statistik dengan menggunakan chi-square diperoleh nilai $p=0,015$, yang berarti terdapat hubungan yang bermakna antara ansietas dengan derajat dispepsia fungsional. Hal ini sejalan dengan penelitian yang dilakukan Kusuma et al yang mendapatkan korelasi positif antara skor keparahan dispepsia (skor NDI, Nepean Dyspepsia Index) dan skor ansietas (skor TMAS, Taylor Manifest Anxiety Scale) atau dengan kata lain semakin besar skor ansietas, semakin besar pula skor dispepsia. ${ }^{5}$

Penelitian telah banyak yang membuktikan pengaruh ansietas terhadap tingkat keparahan gejala 
dispepsia fungsional yang muncul. Berdasarkan penelitian beberapa ahli ansietas berperan dalam peningkatan sensitivitas viseral pada dispepsia fungsional. Penelitian lain menunjukkan adanya kaitan yang kuat antara ansietas dengan gejala mual dan sakit di dada. Berdasarkan penelitian yang juga menggunakan kuesioner HADS, didapatkan ansietas berhubungan dengan dispepsia fungsional. Gangguan gastrointestinal fungsional pada gejala ringan biasanya tidak ditemukan gangguan psikologikal, pada gejala sedang kemungkinan lebih banyak pasien dengan gangguan psikologis, sedangkan pada gejala berat terdapat frekuensi gangguan psikologikal yang tinggi, salah satu contoh gangguan psikologikal ini adalah ansietas. $^{3,6,7,11}$

Ansietas dapat memimbulkan keluhan dispepsia karena ansietas dapat mengaktifkan sistem motor emosional pada korteks serebri yang nantinya rangsangan ini akan diteruskan ke hipotalamus anterior, selanjutnya diteruskan ke nervus vagus dan akhirnya mempengaruhi motilitas dan sensitivitas lambung. Rangsangan pada sistem motor emosional ini dapat diteruskan ke hipotalamus anterior, dan selanjutnya ke hipofisis anterior yang mensekresi hormon kortikotropin. Hormon kortikotropin ini nantinya akan mengaktivasi sel pada korteks adrenal untuk memproduksi hormon kortisol yang selanjutnya merangsang produksi asam lambung dan juga menghambat produksi prostaglandin $\mathrm{E}$ yang bersifat protektif pada mukosa lambung, sehingga hal ini akan menyebabkan mukosa lambung lebih mudah terluka. Oleh karena adanya brain-gut-axis inilah maka gangguan psikologis seperti ansietas dapat mengakibatkan disfungsi fisiologis (motilitas/sekresi/imunitas dan hipersensitivitas viseral yang pada akhirnya menyebabkan timbulnya gejalagejala pada dispepsia fungsional. ${ }^{9,12}$

Hasil penelitian mengenai hubungan depresi dengan derajat dispepsia didapatkan bahwa proporsi responden yang mengalami derajat dispepsia berat cenderung lebih besar pada responden yang depresi dibandingkan dengan yang tidak depresi. Ada sebanyak $50 \%$ responden yang mengalami derajat dispepsia berat yang depresi dan hanya sebanyak
$33,3 \%$ responden yang mengalami derajat dispepsia berat yang tidak depresi, tetapi berdasarkan hasil uji statistik dengan menggunakan chi-square, diperoleh nilai $p=0,516(p>0,05)$. Berdasarkan hasil tersebut maka dapat disimpulkan bahwa tidak ada hubungan yang bermakna antara depresi dengan derajat pasien dispepsia fungsional. Hal ini sesuai dengan penelitian yang dilakukkan oleh Aro et al, dimana pada penelitiannya didapatkan bahwa dispepsia fungsional berhubungan denan ansietas tetapi tidak berhubungan dengan depresi. Penelitian lainnya menunjukkan depresi tidak berkaitan dengan timbulnya gejala pada dispepsia fungsional. ${ }^{4,10}$

Berdasarkan pendapat yang dikemukakan, depresi diperkirakan dapat mengeksaserbasi gejala dispepsia fungsional, dan pada beberapa kasus dapat secara etiologi berhubungan dengan sindrom dispepsia tersebut, meskipun hal ini masih diperdebatkan. Hubungan depresi dengan dispepsia fungsional dapat dijelaskan melalui teori brain-gutaxis, dimana sistem saraf pusat, sistem saraf otonom, dan sistem saraf enterik dapat berkomunikasi secara dua arah dan saling mempengaruhi, dan hal ini lah yang memungkinkan gangguan psikologis seperti depresi dapat mempengaruhi aktivitas motorik, sensorik, dan sekretori pada traktus gastrointestinal dan menyebabkan timbulnya gejala-gejala pada dispepsia fungsional. ${ }^{13,14}$

Berdasarkan penelitian ini didapatkan bahwa tidak ada hubungan depresi dengan derajat dispepsia fungsional. Hal ini berbeda dengan teori yang dikemukakan. Perbedaan ini kemungkinan disebabkan kerena penelitian ini tidak dilakukan langsung pada saat pasien berobat ke RS, sehingga kemungkinan depresi yang dialami responden sudah berkurang atau menghilang karena sudah dilakukan pengobatan.

\section{KESIMPULAN}

Proporsi ansietas pada penderita dispepsia fungsional lebih besar dibandingkan dengan proporsi depresi dan ada hubungan yang bermakna antara ansietas dengan derajat dispepsia fungsional tetapi tidak dengan depresi. 


\section{DAFTAR PUSTAKA}

1. Departemen Kesehatan RI. Profil kesehatan Indonesia. Jakarta: Kementrian Kesehatan RI; 2011.

2. Mahadeva S, Goh KL. Epidemiology of functional dyspepsia: A global perspective. World J Gastroenterol. 2006;12(17):2661-6.

3. Tack J, Bisshops RB, Sarnelli G. Pathophysiology and treatment of functional dyspepsia. Gastroenterology. 2004;127:1239-55.

4. Aro P, Talley NJ, Ronkainen J, Storskrubb T, Vieth $\mathrm{M}$, Johansson SE, et al. Anxiety is associated with uninvestigated and functional dyspepsia (Rome III Criteria) in a Swedish population-based study. Gastroenterology. 2009;137:94-100.

5. Kusuma NHS, Arinton IG, Paramita H. Korelasi skor dispepsia dan skor kecemasan pada pasien dispepsia rawat jalan klinik penyakit dalam di RSUD Prof. Dr. Margono Soekarjo Purwokerto. Mandala of Health. 2011; 5.

6. Oudenhove LV, Vandenberghe J, Geeraerts B, Vos R, Persoons $\mathrm{P}$, Demyttenaere $\mathrm{K}$, et al. Relationship between anxiety and gastric sensorimotor function in functional dyspepsia. Psychosomatic Medicine. 2007;69:455-63.

7. Haug TT, Mykletun A, Dahl AA. Are anxiety and depression related to gastrointestinal symptoms in the general population?. Scand J Gastroenterol. 2002;37:294-8.
8. Taringan CJ. Perbedaan depresi pada pasien dispepsia fungsional dan dispepsia organik. Medan: Universitas Sumatera Utara; 2003.

9. Murni AW. Hubungan depresi dengan infeksi Helicobacter pylori serta perbedaan gambaran histopatologi mukosa lambung pada penderita dispepsia fungsional. Jakarta: Universitas Indonesia; 2010.

10. Micut R, Tanasescu MD, Dragos D. A review of the psychoemotional factors in functional dyspepsia. Revista Medicala Romana. 2012;59: 278-86.

11. Drossman AD. The Functional gastroduodenal disorders and The Rome III process. Gastroenterology. 2006;130:1337-90.

12. Wu JCY. Psychological co-morbidity in functional gastrointestinal disorders: epidemiology, mechanism, and management. J Neurogastroenterol Motil. 2012;18:13-8.

13. Elsayed O, El AT, Asal A, Shahda M. Psychiatric morbidity and somatic symptoms in patients with functional dyspepsia: a comparative study with duodenal ulcer patients. Current Psychiatry. 2006; 13:192-205.

14. Talley NJ, Herrick L, Locke GR. Antidepressant in functional dyspepsia. Gastroenterol. 2010;4:5-8. 